\title{
Retraction: breast cancer surgery in elderly patients: postoperative complications and survival
}

\author{
Nicola Rocco ${ }^{1}$, Corrado Rispoli ${ }^{2}$, Giuseppe Rengo ${ }^{3}$, Gennaro Pagano ${ }^{3}$, Rita Compagna ${ }^{4}$, Michele Danzi ${ }^{4}$, \\ Antonello Accurso ${ }^{4}$ and Bruno Amato ${ }^{4 *}$
}

This article [1] has been retracted by the authors due to significant overlap with a previous publication [2]. Giuseppe Rengo and Gennaro Pagano were not involved in the study and were introduced into the author list by the corresponding author. All authors, including Giuseppe Rengo and Gennaro Pagano, have subsequently agree that they did not qualify for authorship. The remaining authors apologize for any inconvenience caused.

\footnotetext{
Author details

'Department of Biomedical, Surgical and Dental Sciences, University of Milan, Milan, Italy. ${ }^{2}$ Department of General Surgery, Cardinale Ascalesi Hospital - ASL NA1, Naples, Italy. ${ }^{3}$ Department of Translational Medical Sciences, University "Federico II" of Naples, Naples, Italy. ${ }^{4}$ Department of General, Geriatric, Oncologic Surgery and Advanced Technologies, University "Federico II" of Naples, Naples, Italy.
}

Received: 8 January 2015 Accepted: 8 January 2015 Published: 14 January 2015

\section{References}

1. Rocco N, Rispoli C, Pagano G, Rengo G, Compagna R, Danzi M, et al. Breast cancer surgery in elderly patients: postoperative complications and survival. BMC Surgery. 2013;13 Suppl 2:S25.

2. de Glas N, Kiderlen M, Bastiaannet E, de Craen AJM, van de Water W, van de Velde $\mathrm{CJH}$, et al. Postoperative complications and survival of elderly breast cancer patients: a FOCIS study analysis. Brest Cancer Res Treat. 2013;138(2):561-9.

\footnotetext{
* Correspondence: bramato@unina.it

${ }^{4}$ Department of General, Geriatric, Oncologic Surgery and Advanced Technologies, University "Federico II" of Naples, Naples, Italy
}

\section{Submit your next manuscript to BioMed Central and take full advantage of:}

- Convenient online submission

- Thorough peer review

- No space constraints or color figure charges

- Immediate publication on acceptance

- Inclusion in PubMed, CAS, Scopus and Google Scholar

- Research which is freely available for redistribution 